\title{
Menumbuhkan Motivasi Usaha Tawes Crispy pada Rumah Tangga Nelayan melalui Pelatihan dan Pendampingan Kelompok
}

\section{(Fostering Tawes Crispy Business Motivation in Fishermen Households through Training and Group Mentoring)}

\author{
Ratri Virianita ${ }^{1 *}$, Kesha Jonathan ${ }^{2}$, Nadia Putri Firdausa ${ }^{3}$, Husnul Maab ${ }^{4}$, Anzari Nurulia ${ }^{5}$, \\ Naurah Khansa ${ }^{5}$, Khanya Pangestika ${ }^{6}$, Indah Pratiwi Anhar ${ }^{1}$ \\ 1 Departemen Sains Komunikasi dan Pengembangan Masyarakat, Fakultas Ekologi Manusia, Institut Pertanian Bogor, \\ Kampus IPB Darmaga, Bogor 16680. \\ ${ }^{2}$ Sekolah Bisnis, Institut Pertanian Bogor, Kampus IPB Gunug Gede, Jl. Raya Pajajaran, RT.03/RW.06, Babakan, \\ Bogor Tengah, Kota Bogor 16128. \\ ${ }^{3}$ Departemen Agronomi dan Hortikultura, Fakultas Pertanian, Institut Pertanian Bogor, \\ Kampus IPB Darmaga, Bogor 16680. \\ ${ }^{4}$ Departemen Teknologi Produksi Ternak, Fakultas Peternakan, Institut Pertanian Bogor, \\ Kampus IPB Darmaga, Bogor 16680. \\ ${ }^{5}$ Departemen Ilmu Gizi, Fakultas Ekologi Manusia, Institut Pertanian Bogor, Kampus IPB Darmaga, Bogor 16680. \\ ${ }^{6}$ Departemen Ilmu Keluarga dan Konsumen, Fakultas Ekologi Manusia, Institut Pertanian Bogor, \\ Kampus IPB Darmaga, Bogor 16680. \\ *Penulis Korespondensi: E-mail: ratru_v@apps.ipb.ac.id \\ Diterima November 2019/Disetujui Juli 2020
}

\begin{abstract}
ABSTRAK
Ikan tawes (Barbonymus gonionotus) merupakan potensi unggulan di Kabupaten Wonogiri, khususnya di Dusun Watupecah, Desa Gedong, Kecamatan Ngadirojo. Harga jual dan daya simpan ikan tawes sangat rendah sehingga daya jual ikan tawes perlu ditingkatkan dengan melakukan inovasi dalam pengolahan ikan tawes menjadi tawes crispy atau taspy yang dapat menjadi peluang bisnis bagi rumah tangga nelayan untuk meningkatkan pendapatan. Namun inovasi saja tidak cukup, perlu upaya untuk mendorong rumah tangga nelayan mengambil peluang bisnis tersebut dengan menumbuhkan motivasi usaha taspy. Program pengabdian kepada masyarakat ini bertujuan untuk mengetahui keberhasilan pelatihan dan pendampingan kelompok dalam upaya menumbuhkan motivasi usaha taspy pada rumah tangga nelayan. Program ini dilaksanakan menggunakan metode pelatihan dan pendampingan kelompok secara intensif pada 33 rumah tangga nelayan di Dusun Watupecah meliputi pengembangan motivasi dalam kewirausahaan, manajemen perilaku dan waktu, pengolahan produk taspy, dan pemasaran produk olahan taspy. Hasil kegiatan menunjukkan bahwa terjadi perubahan pengetahuan dan motivasi pada rumah tangga nelayan dalam aspek inovasi, impian, dan pengelolaan keuangan. Keberhasilan program pengabdian kepada masyarakat ini dibuktikan dari tumbuhnya motivasi usaha taspy pada rumah tangga nelayan berdasarkan analisis data sebelum dan sesudah pelaksanaan program. Dapat disimpulkan bahwa pelatihan dan pendampingan kelompok merupakan teknik yang efektif dalam menumbuhkan motivasi usaha taspy sebagai peluang usaha produk olahan lokal pada rumah tangga nelayan. Melalui pelatihan dan pendampingan kelompok, para nelayan berkesempatan untuk berdialog, berbagi saran dan pendapat, bekerja sama, dan saling berinteraksi secara positif dalam suasana yang nyaman sehinggga mendukung tumbuhnya motivasi usaha taspy yang kuat pada rumah tangga nelayan.
\end{abstract}

Kata kunci: motivasi usaha, nelayan, pelatihan, pendampingan

\begin{abstract}
Tawes (Barbonymus gonionotus) is top local potential in Wonogiri District, especially in Watupecah Hamlet, Gedong Village, Ngadirojo Subdistrict. The low marketability and storability of tawes requires innovation in fish processing of tawes into tawes crispy chips (taspy) to increase the marketability of tawes which then be a business oppurtunity for fishermen households to increase their income. However, inovation itself is not enough to increase fishermen household income, it requires effort to build business motivation in fishermen households to take business opportunity. This community service program aimed to know the success of training and group mentoring as an effort to foster business motivation of fishermen households. The program was carried out using intensive training and group mentoring methods for 33 fishermen households in Watupecah Hamlet covering the development of business motivation, time and behavior management, processing and marketing of
\end{abstract}


taspy products. The results of the program showed that there was a changed in fishermen's knowledge and motivation on the aspect of innovation, dreams, and financial management. The success of this program is evidenced by the growth of the business motivation of fishermen households based on data analysis before and after the implementation of the program. It can be concluded that training and group mentoring are eff ective techniques in fostering business motivation of fishermen households. Through training and group mentoring the fishermen had chance to dialogue, share suggestion and opinions, cooperate, and interact positively with each other in a comfortable atmosphere as to support the growth of stronger ebusiness motivation of fishermen households.

Keywords: business motivation, fishermen, training, mentoring

\section{PENDAHULUAN}

Salah satu jenis ikan yang terkenal di masyarakat Provinsi Jawa Tengah adalah ikan tawes (Barbonymus gonionotus). Ikan tawes merupakan potensi unggulan di Provinsi Jawa Tengah. Pada 2010 produksi ikan tawes di Provinsi Jawa Tengah mencapai 1.538,8 ton. Ikan tawes diproduksi hampir di seluruh daerah di Provinsi Jawa Tengah. Kabupaten Wonogiri merupakan penyumbang produksi ikan tawes terbesar yang mencapai $14,98 \%$ dari total produksi ikan tawes di Jawa Tengah (Pusat Data Statistik dan Informasi Sekretariat Jenderal Kementerian Kelautan dan Perikanan 2013). Dusun Watupecah turut berkontribusi pada total produksi ikan tawes di Kabupaten Wonogiri. Dusun Watupecah merupakan salah satu dusun dari empat belas dusun di Desa Gedong, Kecamatan Ngadirojo, Kabupaten Wonogiri, Jawa Tengah yang memiliki potensi perikanan berlimpah. Kondisi ini disebabkan aliran Waduk Gajah Mungkur yang melintasi Dusun Watupecah menghasilkan beragam jenis ikan di antaranya, ikan tawes.

Ikan tawes merupakan ikan yang terbanyak ditangkap oleh nelayan Dusun Watupecah, namun, produksi ikan tawes yang tinggi tidak diiringi dengan konsumsi ikan tawes yang tinggi pula di masyarakat. Ikan tawes kurang disukai sebagai pangan yang dikonsumsi oleh masyarakat karena ikan tawes berduri banyak dan halus, serta berbau amis yang cukup menyengat (Chrisdwiniati \& Sulandjari 2015). Padahal, ikan tawes mengandung gizi yang baik untuk kesehatan tubuh, seperti nilai protein sebesar 13\% dan kandungan asam Lemak Omega-3 per 1,5/100 g (Diana \& Safutra 2018) dengan harga di pasaran yang relatif terjangkau oleh masya rakat. Harga ikan tawes dijual Rp 10.000/kg di pasaran relatif lebih rendah daripada ikan nila yang dijual Rp 22.000/kg, ikan lele Rp 18.000/kg, dan ikan patin Rp. $20.000 / \mathrm{kg}$. Oleh karena itu, komoditas ikan tawes berprospek baik, memiliki nilai ekonomis yang cukup tinggi, dapat diproduksi secara massal dan memiliki peluang pengembangan skala industri, serta berpotensi untuk dikembangkan lebih luas di Indonesia (Pratama et al. 2019). Daya tahan kesegaran ikan tawes sangat terbatas sehingga hasil tangkap ikan tawes yang tidak memenuhi kualitas dan tingkat kesegaran yang rendah dihargai oleh pengepul dengan harga yang rendah pula. Nelayan tidak memiliki alternatif lain selain menjual ikan tawes segar kepada pengepul sehingga para nelayan sering mengalami kerugian finansial. Harga jual ikan tawes kepada pengepul pun tidak kunjung meningkat dari tahun ke tahun. Sementara itu, jaring sebagai alat tangkap ikan tawes, mengalami peningkatan secara terus menerus. Kondisi ini menyebabkan pendapatan rumah tangga nelayan Dusun Watupecah dari hasil tangkap ikan tawes kurang dapat diandalkan.

Salah satu upaya dalam merespons persoalan tersebut adalah dengan melakukan inovasi pada ikan tawes. Menurut Rogers (2003), inovasi adalah ide, gagasan, praktik atau benda yang disadari dan diterima oleh seseorang atau kelompok sebagai sesuatu hal yang diterima. Inovasi memiliki lima sifat, di antaranya 1) Keuntungan relatif, yaitu bahwa ide baru memberikan keuntungan ekonomi yang lebih baik daripada sebelumnya; 2) Kompatibilitas, yaitu bahwa ide baru sesuai dengan nilai-nilai, pengalaman dan kebutuhan; 3) Kompleksitas, menyangkut kemudahan atau kerumitan ide baru diimplemetasikan; 4) Triabilitas, yaitu ide baru dapat dicoba dalam skala kecil, dan 5) Observabilitas, yaitu bahwa ide baru dapat dilihat oleh orang lain (Rogers 2003).

Inovasi pada ikan tawes dengan melakukan pengolahan ikan tawes bertujuan untuk meningkatkan harga jual ikan. Berinovasi melalui pengolahan ikan tawes berarti membuat olahan atau menciptakan produk jadi yang berasal dari bahan baku dengan prinsip mengubah fungsi, bentuk, sifat, maupun kualitas ikan tawes segar. Selama ini, ikan tawes diolah dan dikonsumsi 
oleh masyarakat di Dusun Watupecah pada tingkat keluarga saja. Inovasi pengolahan ikan tawes menjadi tawes crispy atau taspy memungkinkan menjadi peluang bisnis yang dapat meningkatkan pendapatan rumah tangga nelayan. Namun, inovasi pengolahan ikan tawes saja tidak cukup untuk peningkatan pendapatan rumah tangga melainkan perlu didukung dengan kewirausahaan rumah tangga nelayan dengan peningkatan motivasi usaha.

Kewirausahaan merupakan salah satu motor penggerak dan dapat menjadi solusi bagi permasalahan ekonomi di Indonesia (Marpaung \& Wardhana 2017), tak terkecuali di Dusun Watuhpecah. Kewirausahaan bukanlah bawaan lahir, melainkan dapat dipelajari dan diajarkan pada setiap individu sehingga ia mempunyai peluang untuk tampil sebagai seorang wirausaha. Wirausaha adalah seorang inovator yang mampu mengubah kesempatan menjadi sebuah ide yang bisa dijual, dapat memberikan nilai tambah melalui upaya, waktu, biaya serta kecakapan dengan tujuan mendapatkan keuntungan (Machfoedz \& Machfoedz 2004). Ilik (2010) menyatakan bahwa seorang individu untuk menjadi wirausaha perlu ditunjang oleh impian. Impian merupakan hasrat dalam diri individu yang menggerakannya untuk maju sehingga dapat dikatakan bahwa impian menjadi sumber motivasi utama. Peran impian sangat penting mengingat resiko kewirausahaan tidaklah kecil. Apabila individu tidak memiliki impian yang kokoh, maka mudah bagi dirinya untuk cepat menyerah. Dengan demikian, perlunya impian dibangun dalam upaya untuk menumbuhkan motivasi usaha taspy yang berkelanjutan pada rumah tangga nelayan di Dusun Watupecah. Pada kajian ini, program pelatihan dan pendampingan kelompok yang dilakukan untuk menumbuhkan motivasi usaha taspy merujuk pada konsep SMART (specific, measurable, achievable, realistic, time bond) (Doran 1981).

Selayaknya motivasi usaha ditumbuhkan melalui pelatihan dan pendampingan kelompok. Motivasi usaha merupakan dorongan yang berasal, baik dari dalam diri maupun luar individu, untuk berperilaku aktif dalam kegiatan kewirausahaan (Aidha 2016). Upaya yang ditempuh untuk menumbuhkan motivasi usaha pada rumah tangga nelayan adalah dengan melaksanakan program pengabdian kepada masyarakat, yaitu memberikan pelatihan dan melakukan pendampingan kelompok pada rumah tangga nelayan di Dusun Watupecah. Tujuan program pengabdian kepada masyarakat adalah untuk mengetahui keberhasilan pelatihan dan pendampingan kelompok dalam upaya menumbuhkan motivasi usaha tawes crispy atau taspy pada rumah tangga nelayan.

\section{METODE PELAKSANAAN KEGIATAN}

\section{Waktu dan Lokasi}

Program pengabdian kepada masyarakat dilaksanakan selama bulan Juni-Juli 2019 di Dusun Watupecah, Desa Gedong, Kecamatan Ngadirojo, Kabupaten Wonogiri. Peserta program pengabdian kepada masyarakat merupakan 33 rumah tangga nelayan yang tergabung dalam Kelompok Nelayan Sumber Rejeki di Dusun Watupecah, Desa Gedong, Kecamatan Ngadirojo, Kabupaten Wonogiri yang pendapatannya mengandalkan pada hasil tangkap ikan di sepanjang Waduk Gadjah Mungkur yang melintasi Dusun Watupecah.

\section{Tahapan dan Metode Pelaksanaan Kegiatan}

Program pengabdian kepada masyarakat ini merupakan sebuah kajian tindakan (research action). Pelaksanaan program pengabdian kepada masyarakat terdiri dari empat tahapan, yaitu: tahap persiapan, pelaksanaan, monitoring, dan evaluasi.

\section{- Tahap persiapan}

Bentuk kegiatan pada tahap persiapan meliputi koordinasi dan sosialisasi program. Koordinasi dan sosialisasi program dilakukan pada berbagai pihak (stakeholders), seperti pemerintah Desa Gedong, pemerintah Dusun Watupecah, tokoh masyarakat, dan kelompok nelayan Sumber Rejeki di Dusun Watupecah. Kegiatan ini dilaksanakan melalui forum Focus Group Discussion (FGD) dengan para stakeholder yang bertujuan untuk mengkomunikasikan gambaran umum program pengabdian kepada masyarakat meliputi tujuan program, sasaran program, bentuk kegiatan, dan luaran program. Koordinasi dan sosialisasi program pada berbagai pihak diperlukan selain untuk memberikan pemahaman tentang program juga untuk mendapatkan izin dan dukungan dari para stakeholder sehingga program pengabdian kepada masyarakat berjalan dengan lancar dan efektif.

\section{- Tahap pelaksanaan}

Bentuk kegiatan pada tahap pelaksanaan meliputi: 1) Meminta peserta program untuk 
mengisi kuesioner pre-test yang bertujuan untuk mengetahui pemahaman dan motivasi usaha peserta program sebelum melaksanakan berbagai kegiatan selama pendampingan kelompok; 2) Memberikan pelatihan pengembangan motivasi kewirausahaan dengan menggunakan metode ceramah dan bertujuan untuk memberikan pemahaman kepada peserta program tentang pentingnya memiliki motivasi dalam kewirausahaan sehingga menunjang peningkatan pendapatan dengan melakukan inovasi pengolahan terhadap hasil tangkap ikan tawes; 3) Memberikan pelatihan dan pendampingan manajemen perilaku dan waktu dengan menggunakan metode ceramah, simulasi dan pendampingan yang bertujuan untuk memberikan pemahaman kepada peserta program tentang pentingnya pengaturan manajemen perilaku dan waktu di dalam pengelolaan usaha ikan tawes dan rumahtangga. Materi yang disampaikan berupa pentingnya menabung untuk menunjang pencapaian impian dari para peserta. Selain itu, memberikan pendampingan melalui simulasi cara memilah uang bisnis dan rumahtangga dengan beberapa wadah yang telah disediakan, serta pembukuan sederhana sebagai bentuk disiplin perilaku dalam berwirausaha; 4) Memberikan pelatihan dan pendampingan pengolahan ikan tawes. Kegiatan ini menggunakan metode praktik dan pendampingan yang bertujuan untuk memberikan keterampilan kepada peserta program tentang pentingnya inovasi dalam pengolahan ikan tawes menjadi produk yang berdaya jual tinggi. Keripik ikan tawes (tawes crispy) merupakan produk olahan yang dipandang berdaya jual tinggi; dan 5) Memberikan pelatihan dan pendampingan pemasaran produk olahan keripik ikan tawes (tawes crispy). Kegiatan ini menggunakan metode ceramah, praktik, dan pendampingan yang bertujuan untuk memberikan pemahaman dan keterampilan kepada peserta program tentang pemasaran dan teknik pemasaran kreatif yang selaras dengan perkembangan zaman, khususnya di era digital.

\section{- Tahap monitoring}

Monitoring dilaksanakan sejak program berlangsung mulai dari tahap persiapan, pelaksanaan hingga tahap evaluasi. Monitoring meliputi pengarsipan data kehadiran peserta, berita acara kegiatan dan dokumentasi foto pada setiap tahap program yang bertujuan untuk mengetahui tingkat partisipasi peserta program pada setiap pelaksanaan tahapan program.

\section{- Tahap evaluasi}

Evaluasi dilaksanakan pada akhir program dengan pengisian kuesioner post-test oleh peserta program. Evaluasi bertujuan untuk mengetahui peningkatan pengetahuan dan motivasi wirausaha pada peserta program setelah keseluruhan program terlaksana dengan membandingkan pesentase hasil pre-test dan post-test.

\section{HASIL DAN PEMBAHASAN}

\section{Koordinasi dan Sosialisasi Program}

Koordinasi dan sosialisasi program kepada berbagai pihak (stakeholders) di Dusun Watupecah merupakan langkah awal dalam tahap persiapan program pengabdian kepada masyarakat. Koordinasi dan sosialisasi program dilaksanakan dalam forum Focus Group Discussion (FGD) di rumah Kepala Dusun Watupecah. FGD atau diskusi kelompok terarah merupakan metode pengumpulan data melalui wawancara dan pembahasan dalam kelompok tentang suatu masalah dalam suasana informal dan santai (Indrizal 2014). Forum FGD diikuti oleh 33 nelayan beserta isteri, Kepala Dusun Watupecah, dan perwakilan aparat Desa Gedong. Forum FGD selain merupakan wadah untuk melakukan pemetaan potensi, masalah dan kebutuhan, menemukan solusi dan menyepakati tindaklanjut, juga merupakan forum komunikasi untuk memberikan pemahaman tentang tujuan program, sasaran program, bentuk program, dan luaran program. Forum FGD menghasilkan kesamaan pandangan dari para stakeholders bahwa Dusun Watupecah merupakan wilayah yang potensial sebagai penghasil ikan tawes sepanjang aliran Waduk Gajah Mungkur. Namun, harga jual, daya simpan, dan daya tarik ikan tawes yang rendah merupakan kendala dan hambatan bagi peningkatan pendapatan rumah tangga nelayan. Salah satu solusi dan upaya untuk memberikan nilai tambah pada ikan tawes adalah dengan memberikan inovasi pengolahan ikan tawes. Dalam forum FGD tersebut disepakati bersama bahwa inovasi pengolahan ikan tawes yang dapat meningkatkan nilai jual ikan tawes adalah keripik ikan tawes yang dinamakan tawes crispy atau disingkat taspy. Namun, agar usaha taspy berjalan secara berkelanjutan disepakati bahwa untuk membangun motivasi rumah tangga nelayan diperlukan pelatihan dan pendampingan kelompok. 


\section{Pelaksanaan Program}

Program pengabdian kepada masyarakat dilaksanakan dalam berbagai bentuk kegiatan, yaitu: pelatihan pengembangan motivasi wirausaha, pelatihan dan pendampingan manajemen waktu dan perilaku, pelatihan dan pendampingan pengolahan produk olahan ikan tawes, serta pelatihan dan pendampingan pemasaran produk olahan ikan tawes.

\section{- Pelatihan}

pengembangan

motivasi wirausaha

Kegiatan ini dihadiri oleh 33 rumah tangga nelayan di Dusun Watupecah yang tergabung dalam kelompok nelayan Sumber Rejeki. Peserta program diberi informasi, pengetahuan, dan motivasi tentang pentingnya kewirausahaan sehingga dapat menunjang peningkatan pendapatan rumah tangga. Kewirausahaan menekankan bahwa inovasi pengolahan terhadap hasil tangkap ikan menjadi produk olahan dapat meningkatkan nilai jual ikan. Dalam hal ini inovasi pengolahan ikan tawes menjadi produk tawes crispy dapat memberikan nilai tambah dan jual ikan tawes. Inovasi tersebut jika ditekuni oleh rumah tangga nelayan dapat berkembang menjadi ladang usaha. Dalam pelatihan ini, diceritakan sosok inspiratif dengan latar belakang yang sama dengan para peserta, namun memiliki impian yang sangat tinggi.

Pada kesempatan itu para peserta diminta untuk menyampaikan impiannya masing-masing berdasarkan SMART (Specific, Measurable, Achieveable, Realistic, Time Bond). SMART merupakan konsep yang diperkenalkan oleh Doran (1981) dalam menyusun target usaha sebagai langkah awal dalam memulai suatu bisnis. "S" dalam SMART berasal dari kata spesific, artinya target usaha dibuat secara terperinci dengan menjawab lima pertanyaan mendasar, yaitu what, why, who, where, dan which. Misalnya, apa target saya? Mengapa saya harus mencapai target tersebut? Siapa saja orang yang akan terlibat? Di mana melakukan usaha? Bagaimana cara melakukan usaha? " $M$ " berasal dari kata measurable, yang artinya dapat diukur sehingga target usaha yang dibangun haruslah dapat menjawab pertanyaan how many? how much? Misalnya, berapa banyak target usaha yang ingin dicapai? bagaimana cara mengetahui target tersebut telah dicapai? A berasal dari kata achieveable, yang artinya target usaha yang sesuai dengan kemampuan sehingga memungkinkan mudah dicapai. Dengan demikian, penting untuk dapat menjawab pertanyaan, seperti: bagaimana cara mencapai target? " $R$ " berasal dari kata realistic yang artinya target usaha sesuai dengan keadaan dan realistis sehingga lebih mudah untuk mencapainya, dengan mempertanyakan seberapa realistis target usaha berdasarkan berbagai pertimbangan. " $T$ " berasal dari kata time bond, yang artinya batas waktu untuk mencapai target usaha, apakah jangka pendek, menengah atau panjang? Dengan menentukan batasan waktu akan memudahkan pemberian penilaian terhadap pencapaian target usaha, apakah sudah mencapai target atau masih kurang?

Selama kegiatan ini para peserta sangat antusias mempelajari bagaimana pentingnya berwirausaha, bagaimana menjadikan impian sebagai motivasi utama dalam berwirausaha, dan bagaimana membentuk impian yang SMART. Gambar 1 menunjukkan kegiatan pelatihan pengembangan motivasi usaha.

\section{- Pelatihan dan pendampingan manajemen waktu dan perilaku}

Kegiatan ini juga dihadiri oleh 33 rumah tangga di Dusun Watupecah yang tergabung dalam kelompok nelayan Sumber Rejeki. Pelatihan bertujuan untuk memberikan pemahaman kepada peserta program tentang pentingnya manajemen (pengelolaan) waktu dan perilaku di dalam rumah tangga dan usaha. Pengelolaan waktu (time management) adalah tindakan untuk memperoleh sebuah penggunaan waktu yang efektif ketika melakukan tindakan tertentu yang megarah pada tujuan (Goldsmith 2010). Dalam konteks kewirausahaan, manajemen waktu menjadi hal yang penting dilakukan agar usaha berjalan sesuai dengan target. Adapun manajemen perilaku meliputi manajemen keuangan yang juga diperlukan dalam menjalankan usaha. Manajemen keuangan merupakan ilmu atau praktik mengelola uang atau aset lainnya (U'rfillah \& Muflikhati, 2017). Dalam hal ini para peserta diberikan pengetahuan tentang pentingnya pengelolaan

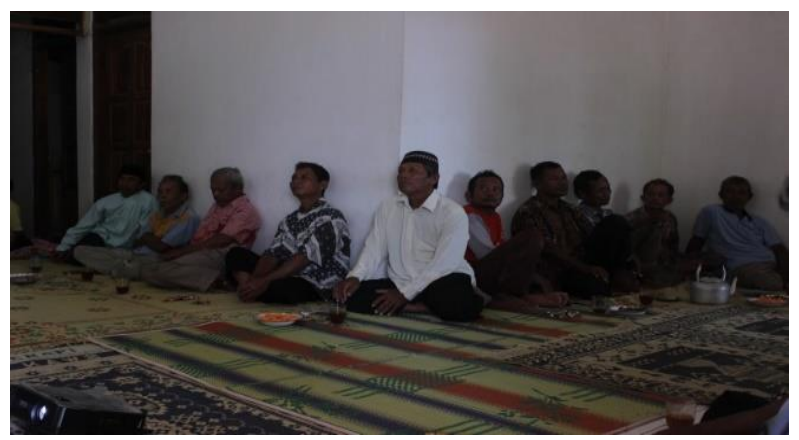

Gambar 1 Pelatihan pengembangan motivasi usaha. 
uang rumahtangga dan menyisihkan uang untuk ditabung.

Materi yang disampaikan berupa pentingnya menabung untuk menunjang pencapaian impian dari para peserta program. Dalam pelatihan diberikan juga pendampingan melalui simulasi cara memilah uang rumah tangga dan bisnis dengan beberapa wadah yang telah disediakan, serta pembukuan sederhana sebagai bentuk disiplin perilaku dalam berwirausaha. Uang yang digunakan untuk konsumsi rumah tangga, seperti uang listrik, sekolah, dan kebutuhan rumah tangga lainnya disimpan dalam sebuah amplop bertuliskan "Uang Rumah tangga”. Adapun uang yang digunakan untuk keperluan bisnis disimpan dalam amplop lainnya yang bertuliskan "Uang Bisnis". Pemasukan dan pengeluaran pada masing-masing amplop harus dicatat dalam pembukuan. Hal ini bertujuan agar para peserta memahami bahwa pengeluaran dan pendapatan pribadi tidak tercampur dengan usaha (Sugiono 2009). Dalam pelatihan juga disampaikan materi manajemen waktu dalam rumah tangga dengan menekankan pentingnya pembagian tugas dalam rumah tangga sesuai dengan skala prioritas yang dirancang oleh rumah tangga masing-masing. Para peserta mengikuti pelatihan ini dengan sangat antusias mengingat pelatihan menjawab permasalahan yang dialami oleh peserta, seperti masalah pengaturan waktu dan perilaku yang kurang konsisten.

\section{- Pelatihan dan pendampingan pengolahan produk olahan ikan tawes}

Pelatihan diawali dengan penjelasan mengenai inovasi dan produksi, macam-macam contoh olahan ikan tawes, bahan dan alat pembuatan produk, dan cara pengolahannya (Gambar 2). Kegiatan ini dilaksanakan bersama dengan peserta program dalam penyediaan alat dan bahan pengolahan keripik ikan tawes, tawes crispy. Peralatan yang dipersiapkan, yaitu wajan, kompor, wadah baskom, spatula, cobek, ulekan, kertas koran bekas, timbangan, kemasan, dan label. Bahan baku yang dipersiapkan untuk pengolahan produk terdiri dari: ikan tawes berukuran sedang, minyak nabati, tepung beras, tepung tapioka, bawang putih, garam, kunyit, ketumbar, kemiri, soda kue, dan penyedap makanan. Soda kue pada pengolahan keripik ikan tawes diperlukan untuk membuat keripik ikan tawes menjadi lebih renyah. Dalam pengolahan ikan tawes menjadi keripik ikan tawes memerlukan teknik pengolahan yang tepat. Penggunaan jumlah bahan yang tidak tepat dapat membuat keripik menjadi terlalu lunak dan tidak renyah. Ikan tawes harus digoreng sebanyak dua kali. Hal ini bertujuan agar duri ikan menjadi renyah dan bisa langsung di makan, tanpa harus dipisahkan. Metode penirisan minyak pada hasil goreng pertama juga harus dilakukan secara tepat, yaitu dengan menunggu ikan sampai benar-benar dingin setelah penggorengan pertama (Gambar 3). Posisi kepala ikan yang sedang ditiriskan harus menghadap ke bawah agar minyak dapat tiris dengan cepat. Para peserta mengikuti kegiatan pelatihan ini dengan antusias karena kegiatan ini pun diiringi dengan demo masak pengolahan keripik ikan tawes sehingga peserta lebih mudah memahami dan dapat praktik langsung dalam pengolahan keripik ikan tawes.

\section{- Pelatihan dan pendampingan pemasaran produk olahan ikan tawes}

Pelatihan diawali dengan penyampaian materi mengenai pentingnya pemasaran, jenisjenis pemasaran, dan beberapa teknik pemasaran kreatif yang telah dilakukan oleh beberapa produk lokal Indonesia. Jenis pemasaran ada dua macam, yaitu pemasaran secara offline dan online. Bagi peserta, pemasaran yang lebih menarik adalah pemasaran menggunakan media offline, yaitu berupa word of mouth. Para peserta belajar berbagai jenis cara mempromosikan

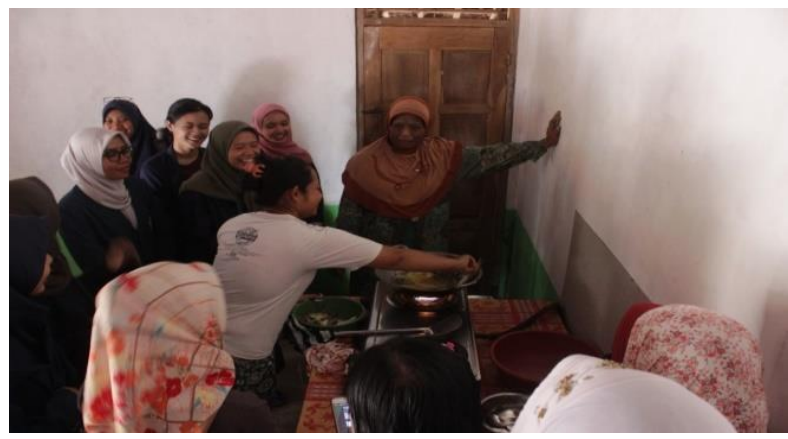

Gambar 2 Pelatihan dan pendampingan pengolahan produk olahan ikan tawes.

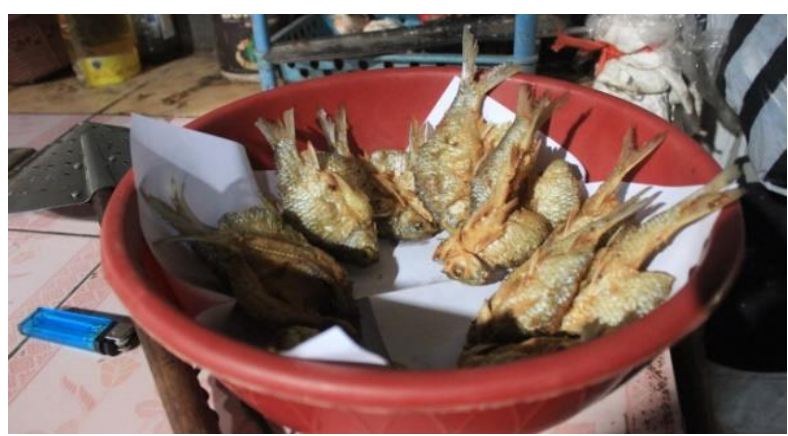

Gambar 3 Metode penirisan minyak pertama keripik ikan tawes. 
produk olahan ikan tawes secara langsung. Peserta juga belajar tentang teknik pemasaran secara online. Tidak dipungkiri bahwa Dusun Watupecah tergolong dusun yang maju di Desa Gedong. Para warganya sudah memhami dan mengerti tentang penggunaan teknologi informasi dan komunikasi sebagai media jualbeli. Tutorial menjual produk olahan taspy melalui media whatsapp, instagram, dan website desa diikuti oleh para peserta dengan tekun. Namun, website Desa Gedong belum optimal dan cenderung tidak aktif dan belum dimanfaatkan secara optimal dalam menyampaikan hasil potensi desa. Pada kesempatan ini fitur-fitur baru untuk produk olahan Desa Gedong, khususnya produk olahan keripik ikan tawes Dusun Watupecah, ditambahkan di dalam website desa sebagai media promosi dan pemasaran produkproduk khas Desa Gedong. Pada pelatihan ini, para peserta juga diberikan pemahaman mengenai pentingnya kemasan, fungsi kemasan, dan hal-hal penting yang harus dicantumkan dalam kemasan, serta peserta juga melakukan pengemasan produk olahan keripik ikan tawes yang dengan kemasan dan label yang telah disediakan (Gambar 4). Demo pengolahan dan pengemasan dilakukan agar para peserta menyadari bahwa meningkatnya harga jual produk ditentukan oleh inovasi-inovasi yang dilakukan oleh para peerta.

\section{Monitoring dan Evaluasi Program}

Monitoring program dilaksanakan sejak tahap persiapan, pelaksanaan, hingga evaluasi melalui pengarsipan daftar kehadiran peserta, berita acara kegiatan, dan dokumentasi berupa foto dan video. Monitoring program bertujuan untuk mengetahui tingkat partisipasi peserta program dalam setiap tahapan. Adapun evaluasi program dilakukan terhadap keseluruhan program dengan melakukan pre-test dan post-test pada pelaksanaan program. Evaluasi program bertujuan untuk mengetahui keberhasilan program

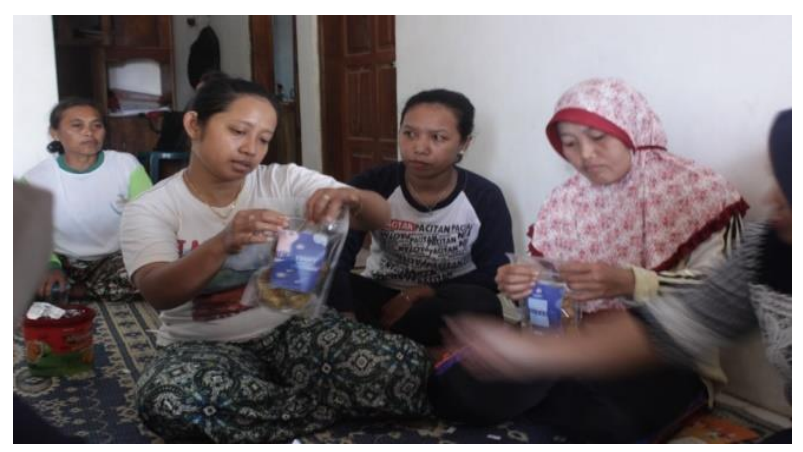

Gambar 4 Pengemasan produk olahan ikan tawes. dalam menumbuhkan motivasi wirausaha peserta program melalui pelatihan dan pendampingan kelompok. Evaluasi program meliputi evaluasi pengetahuan dan motivasi wirausaha.

Evaluasi pengetahuan kewirausahaan pada peserta program disajikan Gambar 5. Gambar tersebut memperlihatkan peningkatan pengetahuan kewirausahaan pada aspek pemasaran setelah pelaksanaan program. Pengetahuan kewirausahaan peserta program pada aspek pemasaran sebelum pelaksanaan program sebesar 93\% meningkat sebesar 4\% menjadi $97 \%$ setelah pelaksanaan program. Adapun pengetahuan kewirausahaan pada aspek produksi, fungsi kemasan dan pemanfaatan website sebelum dan sesudah pelaksanaan program tidak menunjukkan perubahan. Pengetahuan pada aspek produksi meliputi pengetahuan pada produk usaha "taspy" yang akan dipasarkan, seperti jumlah dan kualitasnya. Pengetahuan pada aspek fungsi kemasan meliputi pengetahuan tentang fungsi perlindungan kemasan terhadap benturan, hujan, atau debu terhadap produk usaha "taspy". Pengetahuan pada aspek pemanfaatan website meliputi pengetahuan kegunaan website Desa Gedong dalam memasarkan produk usaha "taspy". Pengetahuan kewirausahaan peserta program dalam aspek produksi, fungsi kemasan dan pemanfaatan website sudah tinggi, yaitu 100\%.

Pada umumnya, para peserta program sudah megetahui dan memahami bahwa peningkatan pendapatan rumahtangga dapat dilakukan dengan wirausaha, namun terkendala dengan pemasaran produk olahan sehingga peningkatan pendapatan kurang tercapai. Meningkatnya pengetahuan kewirausahaan peserta program dalam aspek pemasaran menunjukkan bahwa pelatihan dan pendampingan kelompok merupakan teknik yang efektif dalam meningkatkan pengetahuan kewirausahaan peserta program. Evaluasi motivasi wirausaha berdasarkan aspek inovasi, impian, pengelolaan waktu, dan pengelolaan keuangan disajikan Gambar 6.

Gambar 6 memperlihatkan peningkatan motivasi usaha peserta program pada aspek inovasi, impian dan pengelolaan keuangan setelah pelaksanaan program. Motivasi usaha pada aspek inovasi meliputi dorongan untuk berkreasi atau menciptakan suatu produk baru. Motivasi usaha peserta program pada aspek inovasi sebelum pelaksanaan program sebesar $74 \%$ meningkat sebesar $23 \%$ menjadi $97 \%$ setelah pelaksanaan program. Motivasi usaha pada aspek impian meliputi dorongan untuk 


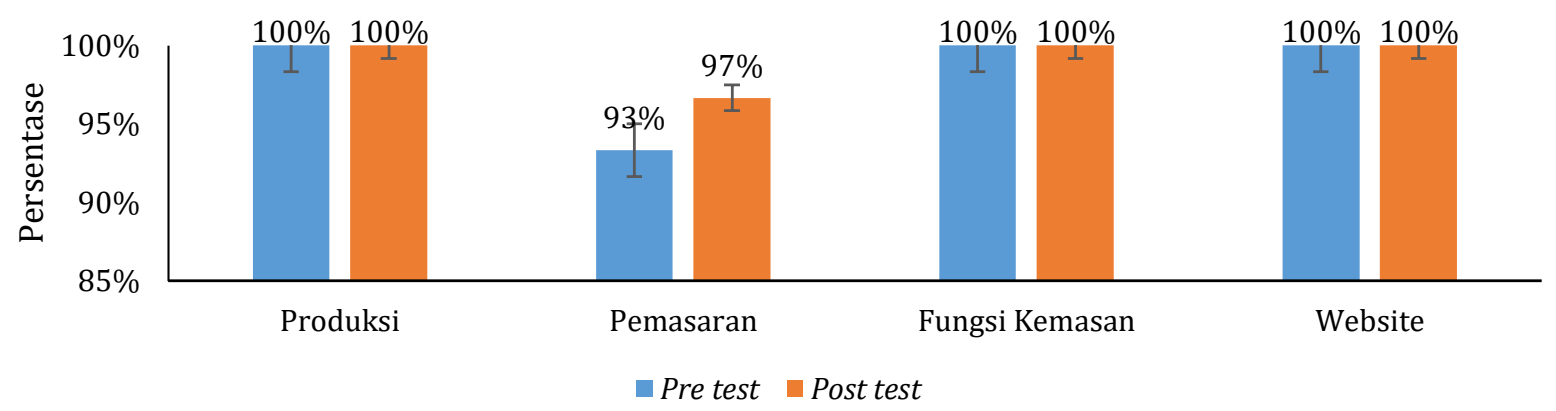

Gambar 5 Hasil pre-test dan post-test pengetahuan kewirausahaan.

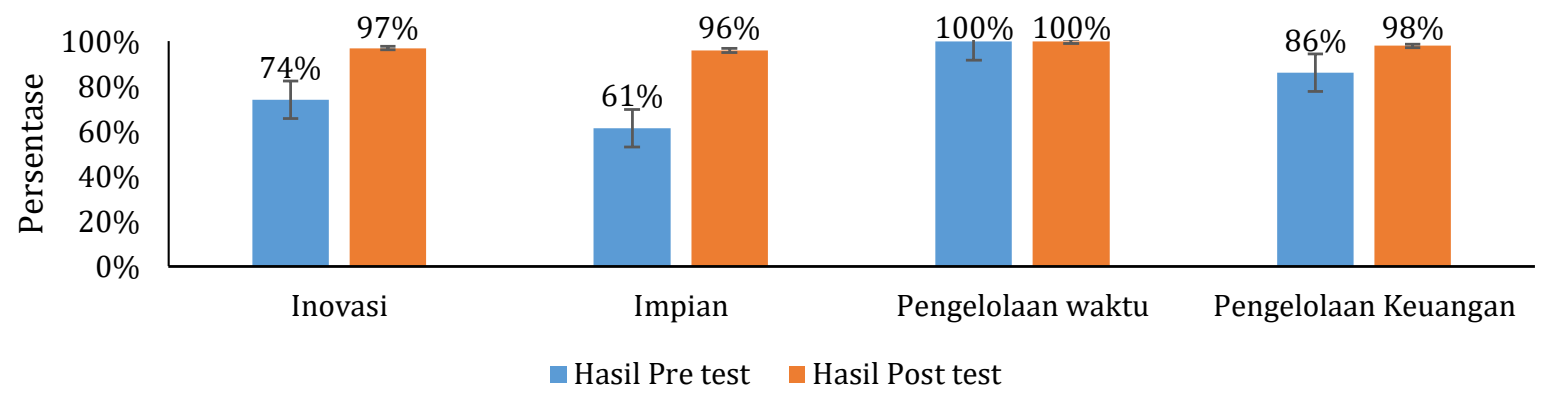

Gambar 6 Hasil pre-test dan post-test motivasi usaha.

membuat masa depan lebih baik. Motivasi usaha peserta program pada aspek impian sebelum pelaksanaan program sebesar $61 \%$ meningkat sebesar 35\% menjadi 96\% setelah pelaksanaan program. Lalu, motivasi usaha pada aspek pengelolaan keuangan meliputi dorongan untuk menentukan alokasi dana bisnis. Motivasi usaha peserta program pada aspek pengelolaan keuangan sebelum pelaksanaan program sebesar $86 \%$ meningkat sebesar $13 \%$ menjadi $98 \%$ setelah pelaksanaan program. Adapun motivasi wirausaha peserta program pada aspek pengelolaan waktu sebelum dan setelah pelaksanaan program tidak mengalami perubahan. Hal ini karena motivasi usaha peserta program dalam aspek pengelolaan waktu sudah tinggi, yaitu 100\%. Berdasarkan hasil pre-test dan post-test dapat dinyatakan bahwa pelatihan dan pendampingan kelompok merupakan teknik yang efektif dalam menumbuhkan motivasi wirausaha peserta program.

Keberhasilan program ini sejalan dengan Sutarto et al. (2018) yang menemukan model pemberdayaan masyarakat melalui pelatihan kecakapan hidup berbasis keunggulan lokal. Pelatihan merupakan suatu upaya yang disengaja, bertujuan, dan terkendali agar orang lain belajar dan terjadi perubahan perilaku yang relatif menetap sebagai hasil dari pengalaman (Miarso 2004). Adapun belajar itu sendiri merupakan suatu proses mental yang bersifat personal, berlangsung dalam interaksi aktif dengan lingkungan untuk menghasilkan perubahan dalam pengetahuan, keterampilan, dan sikap (Winkel 1991). Demikian halnya, keberhasilan program ini sejalan dengan Maryani et al. (2018) yang berhasil meningkatkan motivasi berwirausaha peternak sapi perah menggunakan metode pendampingan kelompok.

Pendampingan merupakan strategi yang menentukan keberhasilan program pemberdayaan masyarakat (Karsidi 2002). Bukit (2016) menyampaikan bahwa metode pendampingan kelompok merupakan model belajar kooperatif terstruktur yang menitikberatkan pada lima unsur, yaitu: 1) Saling ketergantungan yang positif, artinya bahwa setiap anggota kelompok mengerjakan tugas kelompok dan setiap tugas kelompok memerlukan kerjasama dari setiap anggota kelompok; 2) Interaksi tatap muka, artinya bahwa setiap anggota kelompok diberikan kesempatan untuk saling bertatap muka dan saling memberikan informasi; 3) Tanggung jawab individu, artinya bahwa setiap anggota kelompok melakukan tugas sesuai dengan tanggungjawabnya untuk keberhasilan kelompok; 4) Komunikasi antar anggota, artinya bahwa setiap anggota kelompok harus saling berkomunikasi dan mempunyai kemampuan komunikasi yang baik: dan 5) Evaluasi proses, artinya bahwa setiap anggota kelompok dapat saling memberikan penilaian terhadap hasil kerja kelompok dan melakukan perbaikan selanjutnya. 


\section{SIMPULAN}

Program pengabdian kepada masyarakat dengan teknik pelatihan dan pendampingan kelompok cukup berhasil meningkatkan motivasi usaha tawes crispy pada rumahtangga nelayan di Dusun Watupecah, khususnya pada aspek inovasi, impian, dan pengelolaan keuangan. Artinya bahwa, kemauan untuk menciptakan seuatu yang baru, kemauan untuk membuat masa depan yang lebih baik, dan kemauan untuk mengalokasi dana bisnis berkontribusi pada tumbuhnya motivasi usaha pada rumahtangga nelayan melalui pelatihan dan pendampingan kelompok. Motivasi usaha menjadi motor penggerak kewirausahaan sehingga sangat diperlukan dalam menjalankan dan memajukan usaha secara berkelanjutan. Melalui pelatihan dan pendampingan kelompok, para nelayan berkesempatan untuk berdialog, berbagi saran dan pendapat, bekerjasama, dan saling berinteraksi secara positif dalam suasana yang nyaman sehinggga mendukung tumbuh dan terpeliharanya motivasi usaha yang lebih kuat pada rumah tangga nelayan. Pelatihan dan pendampingan kelompok merupakan teknik yang efektif dalam menumbuhkan motivasi usaha tawes crispy pada rumahtangga nelayan di Dusun Watupecah. Dengan demikian, perlunya peran multipihak di Dusun Watupecah untuk senantiasa melakukan pelatihan dan pendampingan kelompok pada rumahtangga nelayan dalam upaya menumbuhkan motivasi usaha tawes crispy secara berkelanjutan pada rumahtangga nelayan.

\section{UCAPAN TERIMA KASIH}

Program pengabdian kepada masyarakat ini didanai oleh Lembaga Penelitian dan Pengabdian kepada Masyarakat IPB terintegrasi dengan kegiatan Kuliah Kerja Nyata Tematik IPB 2019.

\section{DAFTAR PUSTAKA}

Aidha Z. 2016. Pengaruh Motivasi terhadap Minat Berwirausaha Mahasiswa Fakultas Kesehatan Masyarakat Universitas Islam Negeri Sumatera Utara. Jurnal Jumantik. 1(1). 42-59.

Bukit H. 2016. Meningkatkan Motivasi Belajar Siswa dengan Menggunakan Model Kooperatif Tipe Student Teams Achievement Devision $(S T A D)$ pada Mata Pelajaran IPS di Kelas V
SDN 107402 Saentis. Elementary School Journal Pgsd Fip Unimed. 5(2): 56-63. https://doi.org/10.24114/esjpgsd.v5i2.4470

Chrisdwiniati OB, Sulandjari S. 2015. Pengaruh Penambahan Daging-Tulang Ikan Tawes Dan Kondisi Ikan Terhadap Sifat Organoleptik Samiler. Jurnal Online Tata Boga. 4(3): 99106.

Diana F, Safutra E. 2018. Pengaruh Pemberian Pakan Alami yang Berbeda pada Benih Ikan Tawes (Barbonymus gonionotus) terhadap Pertumbuhan dan Kelangsungan Hidup. Jurnal Akuakultura. 2(1). 1-9. https://doi.org/ 10.35308/ja.v2i1.769

Doran GT. 1981. There's a S.M.A.R.T Way to Write Management's Goals and Objectives. Management Review. 70. 35-36.

Goldsmith EB. 2010. Resource management for individuals and families. New Jersey (GD): Pearson Education, Inc.

Ilik ME. 2010. Bisnis Jamur Tiram di Rumah Sendiri. Bogor (ID): IPB Press.

Indrizal E. 2014. Diskusi Kelompok Terarah. Jurnal Antropologi: Isu-Isu Sosial Budaya. 16(2): 75-82. https://doi.org/10.25077/ jantro.v16.n1.p75-82.2014

Karsidi R. 2002. Pemberdayaan Masyarakat Petani dan Nelayan. Dalam: Semiloka Pemberdayaan Masyarakat di Jawa Tengah dalam rangka Pelaksanan Otoda, Badan Pemberdayaan Masyarakat Jateng. Semarang (ID): 4-6 Juni 2002.

Machfoedz M, Machfoedz M. 2004. Kewirausahaan: Suatu Pendekatan Kontemporer. Yogyakarta (ID): YKPN.

Marpaung LL, Wardhana A. 2017. Analisis Faktor Motivasi Berwirausaha Mahasiswa Administrasi Bisnis Angkatan 2013 Universitas Telkom. e-Proceeding of Management. 40 (1). 909-914.

Maryani I, Ahda M, Jatmika SED. 2018. Efektifitas Pendampingan Kelompok dalam Meningkatkan Motivasi Berwirausaha Peternak Sapi Perah. Jurnal Pengabdian dan Pemberdayaan Masyarakat. 2(1): 7-13. https://doi.org/10.30595/jppm.v2i1.2059

Miarso Y. 2004. Menyemai Benih Teknologi Pendidikan. Jakarta (ID): Prenada Media. 
Pratama R, Sukendi, Alawi H. 2019. Pengaruh Padat Tebar dan Jenis Pakan terhadap Pertumbuhan dan Kelulushidupan Larva Ikan Tawes (Barbonymus gonionotus). Jurnal Online Mahasiswa (JOM) Bidang Perikanan dan Ilmu Kelautan. 7(2): 1-11.

Pusat Data Statistik dan Informasi Sekretariat Jenderal Kementerian Kelautan dan Perikanan. 2013. Profil Kelautan dan Perikanan Provinsi Jawa Tengah untuk Mendukung Industrialisasi Kp. Sekretariat Jenderal Kementerian Kelautan dan Perikanan, Semarang (ID).

Rogers EM. 2003. Diffusion of Innovations. Fifth Edition. New York (US): Free Press.
Sugiono A. 2009. Manajemen Keuangan untuk Praktisi Keuangan. Jakarta (ID): Grasindo.

Sutarto J, Mulyono SE, Nurhalim K, Pratiwi H. 2018. Model Pemberdayaan Masyarakat Melalui Pelatihan Kecakapan Hidup Berbasis Keunggulan Lokal Desa Wisata Mandiri Wanurejo Borobudur Magelang. Jurnal Penelitian Pendidikan. 35(1): 27-40.

U'rfillah U, Muflikhati I. 2017. Motivasi Berwirausaha, Manajemen Waktu, Manajemen Keuangan, dan Prestasi Akademik pada Mahasiswa Wirausaha. Jurnal Ilmu Keluarga dan Konsumen. 10(1): 71-82. https://doi.org/10.24156/jikk.2017.10.1.71

Winkel S. 1991. Psikologi Pengajaran. Jakarta (ID): Grasindo. 